\title{
'An outward sign of an inward grace': how African diaspora religious identities shape their understandings of and engagement in international development
}

Edward Ademolu ${ }^{\mathbf{1}}$ ORCID http://orcid.org/0000-0002-5122-6232

Department of Methodology, London School of Economics and Political Science, London, UK

\begin{abstract}
Mainstream development discourse and practice often marginalise the significance of 'religion' and 'faith' for international development and humanitarianism. However, recent geo-political events have prompted attitudinal and epistemological developments, with religion and faith considered an almost obligatory agenda for development scholarship. Despite current celebrations, scant attention is paid to the paramount role of religion for faith-based development actors such as, African diaspora individuals and communities. Using focus group discussions, this article examines how the religious-faith identities of UK Nigerians specifically, shape their meanings for and engagement in international development. I reveal that Nigerian remittances and non-monetary contributions and services to their heritage country, are constituted within moral (and cultural) obligations, justifications and values that are distinctly 'religious'. So too, that Nigerians largely construe international development as a demonstrable 'practice' of their faith-based identities. Consequently, I call for a (re)theorisation of development to subsume transnational Afro-religious diasporic performativity. While focused on Nigerians, these findings are nonetheless relevant for wider UK-based African diaspora.
\end{abstract}

Article History: Received 30 January; Accepted 17 August 2020

Keywords: African diaspora, religion, Nigerian, faith identities, international development, remittances.

\section{Introduction: The Religion and International Development Nexus}

Until recently, development discourse overlooked the resourcefulness of religion(s) ${ }^{1}$ and its programmatic and academic application. Undergirded by the early logic-rationalities of enlightenment and modernisation traditions, considerations of religion and 'faith' largely remained peripheral to the technocratic privileging and positioning of international development. The marginality and assumed trivialities of religion's participation in development has been the subject of much critique and commentary. Ver Beek (2000) for example, submitted that religion and spirituality are 'taboo' in development studies while Bornstein (2003), suggests that development is doctrinally and institutionally unaccommodating when it comes to religious matters. Similarly, alluding to development's supposed 'absentmindedness', Selinger (2004) argues that religion appears to be a 'forgotten factor' in development scholarship. This is surprising considering that development

\footnotetext{
${ }^{1}$ Edward Ademolu, E.Ademolu@1se.ac.uk; Department of Methodology, London School of Economics and Political Science, London, UK.
} 
intervention and humanitarianism are constituted in and historicised by religiously rationalised missionaries, enterprises and other attendant faith-inspired materialisms during periods of colonial administration.

Despite long being something of a red-headed stepchild in international development, Balchin $(2007,532)$ and Carbonnier (2013), observe that religion (and the 'f-word' ('faithbased')), is currently basking in the unremitting glory of its long-awaited Cinderella moment, given its 'policy-sexy' significance right now in development agendas. We are reminded by Jones and Petersen $(2011,1292)$ however, that religion's ceremonious address is not the initiative of academia, rather it "came from the development industry particularly the big multilateral and bilateral donors than from universities and research organisations." As such, as recent as the mid-1990s various governments and development institutions reprioritised and strategically engaged with religion and faith-based organisations, with the then James Wolfensohn-helmed World Bank Group trendsetting this attitudinal and policy shift in development-religion cooperation. Indisputably, the catastrophes of September 11 and the ensuing intensification of Islamic and Christian fundamentalism are critical contemporary moments which (re)orientated a shift in messaging towards more explicitly religiously minded discussions for global development agenda (Carbonnier, 2013).

Appropriately, academia has followed suit with a growing body of interesting and engaging development studies literature and commentaries, analysing and critiquing the various meaning(s), centrality and functionalities of religion(s), faith and spiritualities in and for development, especially in relation to the different affordances and limitations of faith-based organisations (FBOs) (See, e.g., Clarke and Jennings 2008; Rakodi, 2007; Deneulin and Bano, 2009; Ager and Ager, 2011). Despite these critical appraisals across the interdisciplinary development field, there is a noticeable absence of scholarship pertaining to the role(s) that 'religiosity' and faith ${ }^{2}$ subjectivities have for diaspora ${ }^{3}$ individuals and communities living in the UK. This is especially true for those of Nigerian heritage, who are actively engaged in international development. By looking at the empirical realities of Nigerian diaspora communities specifically, we better understand the different ways in which the development and religion axis matter for how they comprehend, prioritise and participate in international development. Before we delve into this issue any further, however, it is important that we first take a brief detour towards understanding the contributions and varied forms of engagement that diaspora communities have with international development, and particularly those of Nigerian heritage living in the UK.

\subsection{UK Diaspora and their contributions to International Development.}

Critical and mainstream development studies have increasingly acknowledged, incorporated and analysed diaspora with Global Southern ${ }^{4}$ heritages, as 'development actors', documenting the numerous and differentiated ways that these communities support and participate in international and local forms of development. They have equally shown that diaspora engagement with mainstream $\mathrm{NGOs}^{5}$ and development corporations have important implications for not only their countries of heritage but the overall trajectory of global development (see, e.g., Agarwal and Andrew 2002; Davies, 2012; Wilcock, 2018).

According to Maurice (2014), within the UK specifically, there are approximately 2.8 million people from diaspora communities, accounting for around $4.4 \%$ of the total British population, however it is anecdotally suggested that this number is actually upwards of 4 
million - given contradictions associated with the 'undocumentedness' of those so-called clandestine, illegal and transitionary migrant populations. In terms of Black African identifying communities, the 2011 UK Census recorded 989,628 living in England and Wales, with approximately 20 to $30 \%$ being of Nigerian heritage ${ }^{6}$ (ONS, 2011). With varied established connections to countries engaged with development cooperation, diaspora communities have long contributed financially and in-kind to international development. Despite comprising a small percentage of the UK's overall population, their development contributions via remittances, for example, almost equates the whole of Britain's official development aid budget. So too, private international donations to INGOs are estimated at £1billion, compared to more than $£ 2.5$ billion in formal remittances (The Independent, 2013). A report by the World Bank found that Nigerians, among all UK diaspora, repatriate the most remittances, an estimated $£ 3.27$ million in 2017, with Nigeria now being the largest diaspora-remittance recipient in sub-Saharan Africa and the sixth largest among lower-middle-income-countries (World Bank 2018).

A large body of literature has examined the significance of African diaspora transnational remittances in addressing exigency caused by development-related issues and concerns of poverty and inequality in their countries and communities of heritage. While Nigerians historically contribute to the alleviation of poverty at the household level via direct investments to immediate and extended families. These communities also contribute significantly to the development of vital sectors of the economy and to national growth through other forms of non-monetary social remittances such as, technological skills transfer, expertise, entrepreneurship, and corporate affiliations. Similarly, evidence has pointed to the notable contributions of other actively engaged African diaspora communities such as, Ethiopian, Somali, Eritrean and Ugandan diaspora, whose financial, ideological and political support, lobbying and interference in the international sphere and their 'host' countries, accelerate and prolong peacebuilding efforts (Davies, 2012; Laakso and Hautaniemi, 2014).

However, development NGOs are rarely called-upon as intermediaries by UK Nigerians for these activities, for several important reasons, not least, a fair amount of scepticism towards international and local charities. Ademolu $(2018 ; 2019)$ observed for instance, that Nigerians are highly sceptical of NGOs supposed 'good intentions' for their fundraising appeals given the negative portrayal of Black African poverty. According to Ademolu, this mistrust of NGOs, has caused Nigerians to bypass prominent UK-based povertyalleviating agencies in the mainstream development sector, to remit via religious organisations. It is on this note, that we return to the issue at hand with which this article is concerned. While, literature shows that diaspora communities, including Nigerians, are important drivers of poverty alleviation 'beyond' official aid, making meaningful and productive engagements with international development in their countries of heritage. So too, that religion is development's 'new darling'. There seems to be no scholarly consolidation between the two. As such, little is known about how 'religion' is intimately tied to, and implicated in (the 'whys' behind) some of these transnational activities, and specifically, how the religious identities of Nigerian development actors shape their interpretations of and justifications for international development.

Scholarship on the different ways that development is understood and engaged by various communities is often contextualised by analyses of how it is communicated to general audiences via established motifs of poverty, rooted in media-dominated public representations and discourses of 'charity and 'need' (see, e.g., Ademolu and Warrington, 2019; Smith et al. 2013; Mostafanezhad, 2013). Yet little consideration is afforded to the role and implications of 
religion and communities' faith subjectivities. This critical gulf in knowledge precludes any intellectual engagement with understanding the centrality of religion(s) and religious-faith identities for Nigerian-development relationships. This has important implications for international development studies, policy, and practice(s), especially for the recognition (and inclusion) of diaspora identities for engendering forms of cooperation and alliances with religious members of these communities.

Are we to assume that religion(s) and faith identifications are inconsequential or secondary to how diaspora participate in and negotiate understandings of international development? Or are they much more significant and constitutive than we think? Is there space for religiously informed interpretations of international development that move beyond its definitional and operational preoccupation with technocratic rationality ${ }^{7}$ to allow for new and extended conceptual possibilities? All these speculative questions and theoretical possibilities constitute the intellectual space within which this article is implicated.

\section{Methodology}

A qualitative methodology was adopted using focus group discussions. While not unproblematic, ${ }^{8}$ focus groups are productive in eliciting and analysing peoples' views and encourage debate, discussion, and exchange of multiple and differentiated perspectives, interpretations and experiences unlike individual interviews (Gilbert, 2008). A purposeful sampling approach was used in identification and selection of focus group participants, so that they reflected the research's epistemological and empirical ambitions and provided information-rich material (Onwuegbuzie and Leech 2007; Clough and Nutbrown, 2012).

A total of seven focus group discussions were conducted comprised of 31 participants. All participants were aged between 18-65 years old. Group segmentation/membership was informed by predetermined theoretical propositions and relevant literature. In practice this included first and second generation ${ }^{9}$ Black British people (both male and female) of Nigerian heritage from different educational, professional, and socio-economic backgrounds.

In terms of religious affiliation, $90 \%$ of participants were Christian, while $10 \%$ were Muslim. According to communities and local government research (Change 2009, 33), this appropriately reflects the relatively small proportion of Nigerian Muslims in the UK, "Christians are the dominant Nigerian faith community in England, with only $9 \%$ identifying itself as Muslim”.

It would be remiss of me not to proffer some explanation for the noticeable Nigeriancentricity of this research. Why the preoccupation with the empirical interest of Nigerians? As aforementioned, this article is concerned with the religious-faith identifications of African diaspora communities. Appropriately, Nigerians living in the UK are a model case study for several reasons not least that, in terms of community representation, Nigerians are the largest African national group in the UK where they comprise at least every five Black African (Imoagene 2017). This proportion would be larger if one added first and second-generation diaspora Nigerians, however it is almost impossible to identify them from the census data where they are subsumed in an all-inclusive Black African categorisation, therefore, eliding substantial heterogeneity with respect to national origins. Historical immigration to the UK and especially its histories of colonialism, has also meant that it hosts many different, longestablished, and newly formed communities of Nigerian heritage. Moreover, with Nigeria 
being a former British protectorate and a current member of the British Commonwealth, Nigerian diaspora living in the UK are very well established, with communities concentrated in major cities, and overwhelmingly London, which hosts over 75\% (Imoagene 2017).

The apparent centrality of religion for many Nigerians was another important consideration. Contrary to conventional wisdom about progressive secularisation in contemporary Britain, theologian David Goodhew has argued that this is partially true, given that Christianity for example, is experiencing both death and resurrection ${ }^{10}$ (2012: p. 253) with substantial and sustained growth in Christianity identification and practice among Black minority communities and Black Majority Churches ${ }^{11}$ (BMCs). Nowhere is this more evident than in the borough of Southwark in South East London - the location from which my participants were accessed and recruited. As such, in his ethnography ${ }^{12}$ of Black Christianity in Southwark, Rogers (2013) observed upwards of 250 operational BMCs (with nearly half of these in one postcode), where just over $16 \%$ of the borough's population identify as having African heritage and disproportionately Nigerian.

Colloquially dubbed and officially recognised as the African capital of the UK, Southwark represents the largest concentration of African Christianity in the world outside of continental Africa, with more than 20,000 congregants attending new BMCs every Sunday (Rogers, 2013). As such, Southwark BMCs are predominately African, and overwhelmingly Nigerian-initiated, led and congregated. So too, most (but not all) BMCs identify as 'Pentecostal'13, with others adhering to more traditional denominational forms of Christianity and attendant worship styles such as, Anglicanism and Catholicism. As well as, specific Nigerian (Yoruba ${ }^{14}$ )-congregational styles of Christian adulation.

These realities of Southwark (Black African)-Christianity reflect the 2011 census which documented overall Christian decline in England and Wales, particularly for white British Christians, whereas the growth among Black African Christians was over 100\% (Rogers, 2013). Similarly, in London specifically, the census found an overall $18 \%$ decline among white Christians between 2001-11, with every borough seeing a reduction in white Christian identification compared to $32 \%$ for their Black counterparts. While there is a lack of documentation on Nigerian Muslims in the UK (who are themselves, as indicated earlier, minorities within broader Nigerian communities), it is believed that the vast majority are situated in London and Southwark specifically. Change (2009), estimates that Nigerian Muslim communities stand at around 12-14,000 in number, however this approximation is provisional given the difficulties with recording illegal and other undocumented Nigerians. Moreover, the historical privileging of and preoccupation with British South East Asian Muslim communities in empirical studies and mainstream political discourse complicates this estimation. The Muslim Council of Britain (2015) however, suggest that there are around 272,015 Muslims of African heritage in the UK, comprising about $10 \%$ of the UK's Muslim population, of which Nigerians make up a significant proportion.

While there are no definitive numbers, there is a distinct Nigerian Muslim presence in Southwark with a number of well-established Islamic mosques and community centres, including the Old Kent Road Islamic Centre founded by the Muslim Association of Nigeria UK (MANUK), which has a predominantly Nigerian-Yoruba congregation. As well as, the Peckham Islamic Centre, one of the largest mosques in the borough, where Nigerians comprise about 10\% (Change, 2009). 
In terms of accessing the research participants, most were assembled through a network of personal, social, and professional relationships. The idea was that members of this network would act as primary points of contact, who would, through a snowball sampling strategy, recommend and/or refer other Nigerians who they thought might be interested in the research (Denscombe, 2010). As such, these networks were a "primary vehicle for eliciting findings and insights" (Amit 2000, 2). On other occasions, access was facilitated via gatekeepers in participants' place of worship and commune. Irrespective of recruitment and selection methods, all chosen participants met the criteria of focus group segmentation. Focus group discussions took place in different settings suggested by participants, including local community libraries, faith-based centres, rent-to-use conference rooms and at their homes.

Appropriate ethical approval was sought. All participants were provided with information about the research before participating. Anonymity was assured - pseudonyms are used here. The qualitative data was analysed using a thematic and discourse analysis of audio recorded transcriptions focusing on participant's interpretations and practices of international development.

The decision to examine the empirical realities of Nigerians in the context of religion and international development was also informed by my identification as a Nigerian and my experiences of the interconnectedness of religion and development practices for Nigerian church congregants. My relationship and identification with religion is at once predetermined and concreted by family functioning, as it is iterative, eclectic, and unintentionally anthropological. I am the product of an interdenominational Christian marriage, with a migrantBritish father who was raised in/with the liturgical traditions of Nigerian Anglicanism led by the Church of Nigeria. As well as, a UK-born and partly Nigerian-raised, Roman Catholic mother, whose father, an $\mathrm{Oba}^{15}$, subscribed to the indigenous, precolonial Yoruba religion, spiritualisms, and practices of Ifá ${ }^{16}$. Whose own father before him, my great-grandfather, was conferred with the supreme pontiff-awarded, Knight Papal Order of St Sylvester ${ }^{17}$. While I -a British Nigerian, Southwark-bred, hybrid of Anglo-Catholic-complementarity, spent his formative years attending disproportionately white Catholic churches, before exploring the ceremonial worships styles of many different UK-based Nigerian and BMCs during adolescence and young adulthood.

Within these walls of former bingo halls, leisure centres, school gymnasiums and working men's clubs; salvation, spiritualism, and intimate approximation to the 'Most High' were currencies with a time-limited purchase which warranted a devotion that was Duracell-charged in excess and tamed-vulgarity. No more was this evident than in parishioners' philanthropic contributions via the church and allied religious organisations to support poverty-alleviating missions in African countries, even (and very often) at the expense of real significant personal sacrifice. Be it a bake sale, a sponsored run, a pay-to-watch talent showcase, voluntary church offerings, or shipping second-hand clothing and toiletries to Nigerian orphanages and singlemother shelters. I observed that traditions of transnational 'giving' and charitable servicing, among predominately Nigerian congregations, were deeply implicated within and advocated by their symbolic expressions and materialisms of faith. Suitably, it is here that we now turn to the analytical discussion of the research's empirical findings. 


\section{Faith-Full Support: Diaspora Religious-Faith Identities and International Development}

Colloquially described (in Yoruba) as 'Aladura', meaning 'praying people'; to say Nigerians are generally religious, is an understatement. Whether spoken or unspoken, religion and attendant narratives of faith are the instrumental and instructive rhythms of contemporary Nigerian diaspora realities and identifications. In focus group discussions, participants, notably older members, would often insentiently, preface (and close) introductions, pleasantries, and informal conversations with "We thank God", "God is good", "Alhamdulillah"18 and/or "Inshallah"19. Far from being understood as mere verbal trivialities, these verbalisations of 'gratitudinal thankification' ${ }^{20}$ were the small but very palpable examples of how religious discourse imbue and orientate the 'everyday talk' and lived realities of Nigerians. As such, for Nigerian Christians and Muslims, religion is critical to their interpretations and discussions about identity, and virtually all discussants mentioned that their religious-faith subjectivities meaningfully shape their participation in development-related activities via remittances and other non-monetary transnational contributions. They often referred, or alluded to, some form of moralised rationality or doctrinal justification for their philanthropic 'acts of giving' and support. This is realised in the following statements.

58-year-old Meredith, a self-described "practicing, devout Muslim" shared for example:

“...We have Qur'anic responsibilities ..., social, civic responsibilities, a duty to not only show, but also be, a form of charity to others, especially the underprivileged, you have to show them compassion and consideration, you know? There are several Qur'anic scriptures [...] and in the teachings of Prophet Muhammed that calls attention to social and economic injustice and the sharing of wealth for the welfare of the poor and oppressed. This is extended to your nearest and dearest too, so as instructed ..., when and where I can I give money to family over there [Nigeria] who are struggling. My sister and I banded together to buy our great aunt a small fishing pond, so she could start selling them to the locals and make a decent income ...you see, my benevolent efforts are sacred efforts, my charitable monies are sacred monies ... it is halal wealth shared for the betterment of another"

Much in the same spirit, 25-year-old Christopher an Evangelical Christian and congregant of a Nigerian-BMC, explained:

"I'm a walking-talking Oxfam [laughter]..., in the sense that my faith teaches that looking out for the less fortunate including many of our families back home in Africa is an honourable, blessed act, its almsgiving. There's a verse in the Bible that goes something like ...oh gosh, I put myself on the spot now [laughter]...okay, "And do not forget to share with others, for which such sacrifices God is pleased". Sometimes you forget that just because you're living a fairly decent life here [in Britain] doesn't mean it's all honkey-dory for family back home [Nigeria]..., a lot of my cousins don't even go to school, they can't afford it, I help out the best I can, this is who I am through my faith, what I identify as, my religious DNA." 
While Roman Catholic, videogame designer Nathan, said:

"Helping those in Nigeria is a form of evangelism ${ }^{21}$, it's helping through faith..., it's an outward sign of an inward grace, and as a Catholic I see myself in this calling, this is who I am, what I'm called to do. So, I'll heed to God's call. So, if that means sending my old university textbooks to my uncles, scaffolding a village community centre, or paying for my grandads' monthly check-ups, so be it, it just takes pressure off them."

(Male)

Additionally, Nigerian discussants reported that their development-related activities form a critical part of their ministerial and congregational tasks and responsibilities. Some said for example, that they pledge one-off donations or "commit" to more regular and substantial monetary contributions through tithe ${ }^{22}$ or zakat $^{23}$, in their church and mosque, respectively, often citing their religious-faith identities as a justification for these engagements.

54-year-old Immanuel an Obstetrics and Gynaecology specialist for instance, divulged that he partakes in his church's tithing scheme addressing (among many other things) genderbased poverty and women's rights injustices in Nigeria and other African countries.

"In Seventh-day Adventism ....as a Seventh-day Adventist myself, putting faith into action is encouraged [...] I'm on what you call an Annual Stewardship Programme and basically, I pledge a tenth of my annual salary in support of my church's overseas missionary aspirations like poverty reduction in Africa..., Our aim as Jesus-followers, as Christian-identifying people is to provide financial support in the area of breast and cervical cancer screening for women in Nigeria who can't afford them, as well as, tackle issues of female genital mutilation over there too. We're also trying to provide school uniforms, stationery and books for children who don't have in Africa ..., our goal is to get more girls into schools."

(Male)

Similarly, another participant, 31-year-old Zainab, a Sunni Muslim and congregant of a Nigerian-majority mosque, mentioned that she donates a portion of her salary via Zakat to support "the crisis of hungry Muslims" as she put it, in Northern Nigeria.

"I give Zakat it's an Islamic obligation for the poor and needy, our mosque works closely with the Peckham Muslim Centre and they help allocate the Zakat to different types of causes, recently they've been helping our Hausa brothers and sisters in the northern states of Nigeria ..., they're really poor in that part of Nigeria. They [Muslims in Northern Nigeria] have the highest infant and mortality rates in Nigeria and the lowest rate of child enrolment in schools..., hopefully we can do our little bit..., Inshallah."

Participant commentaries raise some interesting and critical discussions, not least that, Nigerian religion(s) and faith subjectivities are necessarily implicated in, intimately tied to and, instrumental for understanding their interpretations, engagement, and relationship(s) with international development. We understand this interconnectedness in the context of their transnational development-related activities via remittances and allied non-monetary contributions/services to their heritage country, which are noticeably constituted within moral obligations, justifications and values that are distinctly 'religious'. That is, from one statement to another, participants provide individual testimonies of how their Christian and Muslim 
identifications provide the theological and doctrinal vocabularies through which they articulate their interpretations of/for international development. These Nigerian faith(ed) vocabularies of development are centred around and if not, allude to discourses pertaining to embodied notions of humanitarianism, stewardship, reconciliation, compassion, and justice. These are all complementary features which are constituted within some historical conceptual interpretations of international development which frame them within some sort of religiously inspired altruistic rationality, of Florence Nightingale approbation (Corbonnier, 2013).

We understand then that this provides the moralised space and framing within which Nigerian motivations for, interest and involvement in development, are orientated and solidly anchored. Such vocabularies also inform and determine their different priorities and strategies of help and 'giving' in Nigeria. It is unsurprising then, that participants often provide scriptural (that is, Biblical and Qur'anic) or 'parableised' rationalisation for their development participation. As such, these empirical realities suggest that one cannot underestimate or separate the role that religion and attendant faith identifications has in scripting the broader moral narratives and obligations that inform Nigerian values and behaviours. As well as, their vocabularies of justification for engaging in international development.

Similarly, Nigerian interpretations of development as "putting faith into action" as one discussant put it, "helping through faith" and "an outward sign of an inward grace" as another described. So too, referencing development as "evangelism", is critical for (re)theorising the epistemological and operational properties of international development in terms of 'performativity'. That is, Nigerian participants dually conceive development as some sort of indeterminable, discursive construct undergirded by (their) scripturally instructive religious romanticisms and imaginations ${ }^{24}$, but also as an eminently actionable demonstration, measurable 'practicality' or 'performance' of their faith subjectivities. Within this theoretical framing, Nigerian religious-faith identifications are not only implicated in but are necessarily performed (vicariously) 'through' and 'as' development itself. Development in this reconstituted and metamorphosed presentation, suggests a certain palpability, dynamism, adaptability, and multidimensionality which transcend development's secular, technocratic definitional limitations. Towards axes of interpretations of 'performance' from which Nigerian faith identities and 'development' meet and contend in their own performative spaces of interaction.

Development 'as' a religious or faith(ed) performance then, submits that development is and cannot be faith neutral in the context of Nigerian-development interpretations, engagement and practices. As such, religious-faith identities are fundamental for recognising how Nigerian's understand the opportunities and challenges of life in their country of heritage, and how they respond to this. Moreover, to further complicate interpretations of development as religious performativity; in conversations about the interconnectedness of religious identities and development, participants were largely self-referential when rationalising their religiousdevelopment activities, with statements such as, "this is who I am through my faith...my religious DNA", "I see myself in these acts of God's calling" and "this is me and I am this...sending money is a reflection of me". Not only do these statements reinstate the intertwining of Nigerian religious identifications with development practices but also that participants conceive themselves (their religious/faith identities), as embodiments and/or conceptual reifications of international development itself.

As such, for Nigerians development is at once a religious performance and a material expression, extension of their 'religious selves'. It comes as no surprise then that Christopher 
would describe himself as a "walking-talking Oxfam" (cited above), with Oxfam, an NGO, being a metaphorical apparatus and an official interlocutor of development and by extension, a signification to resemblance of Christopher's sense of religious self as understood in his development acts.

Relatedly, it is worth noting how Nigerian participation in more formal religious obligations such as, tithing and Zakat, as evidenced by Immanuel's involvement in the "Annual Stewardship Programme" and Zainab's observance of Zakat, demonstrate how churches and mosques incorporate acts and discussions of development in their practices. As such, there is some mutuality or reciprocity between Nigerian transmutation of 'faith into practice' and how the practice of that faith in more formalised worship, also simultaneously evokes this.

Interestingly, Nigerian commentaries also reveal a supplementary 'self-servicing' motivation behind their development-related engagements that goes beyond (or perhaps, is parallel to) the guise of their religiously inspired altruistic justifications. What I mean by this is that Nigerian's material and immaterial transnational contributions and acts of service are not entirely selfless, unconditional generosities. Rather, they are nonpecuniary reward-based reciprocal demonstrations of righteousness and salvation, performed with the hope to receive (and negotiate) God's atonement and forgiveness in the afterlife. With that said, 'doing' development via (or as) faith has a dual functioning for Nigerians. Firstly, it serves to address and respond to financial and socio-political exigency informed by development-related issues and concerns in their country of heritage. Secondly, it is a means to self-servingly satisfy the 'eligibility criteria' upon which God's favour is received.

On a similar note, with references to development activities as "sacred monies", "sacred efforts", "blessed acts" and "Christ-filled holy contributions" as another described, adds a new filter for understanding how Nigerian faith communities conceptualise international development. Whereby Nigerian remittances and non-monetary transnational contributions are not just pecuniary materialisms, they are conceived as somehow imbued with spiritually transformative properties that transcend monetary 'marketplace value'. This conceptualisation of development contributions by Nigerians affords it a signification that is distinctly sacred and consecrated in a religiously moralised economy of development ${ }^{25}$. Within this frame, Nigerians' supposed sacralised development contributions, function within systems of meaning and practices associated with and constituted by moral expectations and theological obligations which frame their religious identifications.

Participants also mentioned how their development participation and construal is equally informed by, and is implicated in, their cultural identities and family community life. Nigerians, like many other African communities, have strong intergenerational relationships and are connected through personal histories, shared cultural values, and acknowledged traditions of culturally informed family obligation and reciprocity (Davies, 2012).

Several revealed that they support their families due to familial obligations as "Nigerians" and/or "African": they give to demonstrate reverence, respect and gratitude to parents and grandparents; protect the honour of their families' reputation; and or assure their economic wellbeing. For participants, regardless of their generation, this sense of cultural duty was deeply held. However, what was particularly interesting is that while cultural identifications were cited as additional justifications for engaging in transnational philanthropic activities, these justifications were incidentally religious. That is, liturgical, scriptural, and philosophical aspects of their religious identities are instrumentalised in their cultural obligations "to give". As such, it was generally understood among Nigerians that to "culturally 
identify as Nigerian is to be religious" as one put it, highlighting the mutual inclusivity of both their cultural and religious identifications. It was not uncommon for participants therefore to preface or contextualise their cultural obligations for development activities within religious sentiments, often citing the instructions and lessons of religious text and parables.

In her group discussion, 48-year-old Ayomide for instance, emphasised the religiouscultural significance of financially supporting her relatives in Nigeria, while living in the UK.

\begin{abstract}
"In our communities we're circumscribed by our traditions, they're not part of a bygone age or
${ }^{26}$ irrelevant just because I'm not there [Nigeria], I can't imagine foregoing my cultural duty to support my family back home, just as they did for me. It's about being a dutiful child to my parents, no matter how old I am, I will forevermore be their child, their junior, and so, I have to help them out when and where possible. It's a two-way street, as the bible says 'let your father and mother be glad; let her who bore you rejoice""
\end{abstract}

(female)

Similarly, 29-year-old Promise, expanded on how Nigerian expectations of roles, obligations and support within their families and communities are framed by cultural and religious orientations and reciprocity. He explained:

“...It's kinda like you've scratched my back, so I'll scratch yours, you know? It's give and take. Our parents, grandparents, and great aunts, whoever, have sacrificed, shed blood, sweat and tears which they ploughed into nourishing their children's futures. Me helping them out is a return on their investment, their parenting is rewarded by the receipt of my financial support among other things. That's just our culture... our faith, it's all about being a respectful Nigerian, being an upstanding African, it's what we do, we are taught as Christians to honour our father and mother and share what we have with them"

(Male)

Again, these participant commentaries are revelatory in that they corroborate important discussion points in terms of understanding the constitutive role that Nigerian religious identification and 'narratives of faith' has for their engagement in and understanding of international development. We understand from group discussions that there appears to be a certain depth, quality and foregrounding of religion and religious identification for/among Nigerians that even subsumes, transcends, works adjacent to, or which frames the rationalities of their cultural-obligatory identifications for development participation. Within this frame, Nigerians not only metaphorically conceive international development as religious performativity (as aforementioned) but more importantly, a performativity (a faith(ed) practice) that is also demonstrably culturally 'Nigerian' indeed 'African', in Promises' case. This implores a certain rethinking of international development that includes interpretations which frame it within ideas (and practices) of what can be best described as some sort of 'transnational Afro-religious diasporic performativity'. ${ }^{27}$ Whereby, religiously-inspired development acts (monetary and non-monetary transnational contributions to 'home' countries) by African diaspora communities, and Nigerians specifically in this case, are legitimised as culturally-distinct forms, articulations and/or performances of international development 


\section{Discussion and Conclusion}

This article's central thesis necessarily complicates, challenges and 'speaks back to' established interpretations of the international development and religion nexus as seemingly 'taboo', inconsequential and worse, non-existent, as previously discussed (Ver Beek, 2000; Bornstein, 2003; Selinger 2004). It does this by making meaningful contributions to the burgeoning international development scholarship which demystify normative assumptions of development's secularism (Clarke and Jennings 2008; Rakodi, 2007; Deneulin and Bano, 2009; Ager and Ager, 2011). Whereby, alternative iterations of international development are offered which emphasise the material and metaphorical functionality and centrism of religious identification for Nigerian comprehension and practices of development. Relatedly, given fraught relationships between some Nigerian diaspora communities and development NGOs (Ademolu, 2018; 2019), this article is equally useful for understanding that any recognition of religion's significance for and 'as' development among Nigerians, may engender particular forms of productive cooperation and alliances with these faith communities.

It makes important and unique contributions to mainstream and critical scholarship in the interconnected fields of African diaspora identification and international development. It began with the question, or a series of speculative questions and theoretical possibilities, pertaining to the impact that Nigerian religious-faith identities have for how they comprehend and participate in international development. While there is a growing body of interesting and critical development studies literature and commentaries, analysing and critiquing the various meaning(s), centrality and functionalities of religion(s), faith and spiritualities in and for international development. Scant attention has been paid to African diaspora populations - as faith communities, who engage in international development via transnational (monetary and in-kind) contributions to their heritage countries.

Appropriately, by examining the empirical realities of Christian and Muslim Nigerians as an exemplar case study, it has revealed how religion, 'narratives of faith' and attendant religious identifications are instrumental for understanding how these communities - as lay 'development actors' - interpret and participate in international development.

This is understood in their religiously moralised rationalities, justifications, and theological obligations for participating in development-related activities via private remittances and allied non-monetary transnational contributions in their places of worship to their country and communities of heritage. That is, for Nigerians, their Christian and Muslim identifications provide the theological and doctrinal foundation and vocabulary through which they articulate (and demonstrate) their interpretations of/for international development. These faith(ed)-vocabularies of development are undergirded by and organised around embodied discourses of humanitarianism, compassion, and justice. So too, the significance of this religious moralising by Nigerians extends to their conceptualisations of their development activities as 'consecrated acts' operating within systems of meaning and practices associated with and constituted by, moral expectations and theological obligations that frame and which signify their religious/faith orientations.

Within this frame, development is also understood by Nigerians as a 'performance', practicality or an 'action-ing' of their religious-faith identities and of their embodied 'religious selves'. Whereby, their intangible, symbolic religious sensibilities and subjectivities are 
transmuted into palpable, material forms. That is to say, they are concrete "outward signs of an inward grace" which are used to mitigate exigency caused by very real development-related issues and concerns of poverty and inequality affecting their families and communities in continental Africa. As well as, material attempts at receiving God's favour.

In this sense, Nigerian religious-faith identifications are not only implicated in but are necessarily performed 'through' and 'as' development itself. Moreover, Nigerians not only construe international development as 'religious performativity' but a performativity, a faith(ed) practice, that is inclusive of their equally religiously informed cultural identities. Interestingly, while these religious 'performances' of development accommodate participants' identities as 'Nigerian', they are not necessarily 'inclusive', or prioritised across faith lines but along them. That is, Christian and Muslim participants target their donations and remittances to their own respective religious communities in Nigeria as is shown by 54-year-old Christian, Immanuel, and Zainab the 31-year-old Sunni Muslim.

\section{Notes}

${ }^{1}$ There is no authoritative definition of religion. Adopting a substantive perspective which analyses Religion in terms of its content and essence such as a widespread belief in (a) God and the 'supernatural/transcendental', this article interprets religion as, a unified system of [doctrinal and/or scriptural] beliefs and practices relative to the worship of a supernatural being that is, a personal 'God' that is above nature and which transcends scientific comprehension (See, e.g., Berger 1974 "Substantive versus Functional Definitions"). Within this framing, religion is understood here as 'organisational' or as an institution in which systems of belief are formally organised, codified and ratified via interpretations of sacred authoritative scriptures (e.g. The Bible, Quran) and/or rites.

2 Intimately-tied to this article's interpretation of 'religion', 'faith' is used here to describe those with private, personal and 'individualised' relationships with a supernatural being that is, 'God' without necessarily attending (or feeling the need to attend) an organised place of worship - for a variety of reasons. These people 'of faith' may also (partially) subscribe to, and constitute certain (sometimes obligatory) doctrinal, scriptural, and/or ceremonial values and observances in their everyday lives.

${ }^{3}$ The term diaspora is historicised by conceptual and definitional inconsistences (See, e.g., Kenny, 2013), here it applies to migrant communities who moved from their continent/countries of heritage and have now settled (and in the case of their offspring, born) in the UK.

${ }^{4}$ The "Global South" is used here to refer to countries and world regions often called developing/underdeveloped, "Third World", non-Western. When used, the term is placed in quotation marks. For a detailed discussion of the problems with, and pitfalls of, these terminologies, see, e.g., Chant and Mcilwaine (2009).

${ }^{5}$ Non-Governmental Organisations.

${ }^{6}$ Nigerian-born migrants and British-born children of.

${ }^{7}$ Adapting Meynaud's $(1969,31)$ definition, technocratic rationality refers to "[an approach to and understanding of international development] in which technically trained experts rule by virtue of their specialised knowledge, [expertise] and position in dominant political, [academic] and economic institutions"

${ }^{8}$ See, e.g., Onwuegbuzie, Leech and Collins (2010) 'Innovative data collection', for critical discussions about methodological and theoretical issues such as 'group think' and reflexivity.

${ }^{9}$ In the context of this research this included those people born and/or who schooled in the UK, having arrived as children, or those who were the children of parents who had.

${ }^{10}$ See, Goodhew (2012) 'Church Growth in Britain' 
${ }^{11}$ Black majority church, a church in which over half of its congregation is Black. According to Aldred (2007) 'Black Churches', there are 500,000 Christians in black majority churches.

${ }^{12}$ See Rogers (2013) 'Being Built Together'

${ }^{13}$ Those Christians who look to the experience of the Holy Spirit by Jesus' disciples at Pentecost

${ }^{14}$ A Nigerian ethno-linguistic community and an indigenous Nigeran religion

${ }^{15}$ A Yoruba title for certain royal rulers.

${ }^{16}$ A Yoruba religion and system of divination

${ }^{17}$ A knighthood awarded by the Pope as the head of the Catholic Church intended to honour the Roman Catholic laity who are actively involved in the life of the church.

18 'Alhamdulillah' is Arabic for "all praise is due to God alone"

19 'Inshallah' is Arabic for "God Willing" or "if God wills"

${ }^{20}$ A self-coined lingo-poetic phrase, to describe reverential statements of gratitude, awe and respect toward a higher being that is, 'God'

${ }^{21}$ Evangelism is the sharing of the Christian gospel

${ }^{22}$ Tithe is a one-tenth part of annual earnings, paid as a contribution to the Church and clergy.

${ }^{23}$ Zakat is annual payments under Islamic law for charitable and religious purposes

${ }^{24}$ According to Walters (2018) "Religious Imaginations" describes interactions of religion in contemporary geopolitical life.

${ }^{25}$ See Stevanovic (2012) "Remittances and Moral Economies" and Garbin (2017) "Sacred remittances" for similar observations (in the context of migrant remittance-giving) with UK Congolese and Bangladeshi New York immigrants, respectively.

${ }^{26}$ Not to be confused with the indigenous or autochthonous religions of continental and diaspora Africa(ns). Borrowing from Castro and Dawson (2007) "Religion, Migration and Mobility" The term "Afro-religious" - a portmanteau of African and Religious - is used here to refer to the religious and faith subjectivities and practices of/by Black racialised individuals and communities of African heritage. 


\section{Acknowledgements}

Thanks to my PhD supervisors Uma Kothari and Dan Brockington who supported the research from which this paper is taken. I would like to also extend my gratitude to Adriaan van Klinken and Eleanor Power for their feedback on early drafts. The comments of anonymous reviewers were extremely helpful in shaping this paper.

\section{Disclosure statement}

No potential conflict of interest was reported by the author.

\section{Funding}

The material is based upon $\mathrm{PhD}$ research supported by the University of Manchester. 


\section{References}

Ademolu, E. 2018. "Rethinking Audiences: Visual Representations of Africa and the Nigerian Diaspora." PhD diss., The University of Manchester.

Ademolu, E. 2019. "Seeing and Being the Visualised 'Other': Humanitarian Representations and hybridity in African Diaspora identities.” Identities, DOI: 10.1080/1070289X.2019.1686878

Ademolu, E., and S. Warrington. 2019. "Who Gets to Talk about NGO Images of Global Poverty?” Photography and Culture. DOI:10.1080/17514517.2019.1637184.

Agarwal, R., and W. A. Horowitz. 2002. "Are International Remittances Altruism or Insurance? Evidence from Guyana Using Multiple-Migrant Households" World Development 30(11): 2033-2044.

Ager, A., and J. Ager. 2011. "Faith and the Discourse of Secular Humanitarianism" Journal of Refugee Studies 24(3): 456-72.

Aldred, J. 2007. "Black Churches contributing to cohesion or polarising Christians and other faith groups?". Churches Together in England, June 15. http://www.cte.org.uk/Articles/82343/Churches_Together_in/Features_Reviews/Features/Bla ck_Churches.aspx

Amit, V. 2000. Introduction: Constructing the Field. London: Routledge.

Balchin, C. 2007. "The F-Word and the S-Word: Too Much of One and Not Enough of The Other" Development in Practice 17(4): 532-58. doi:10.1080/ 09614520701469500

Berger, L.P. 1974. "Some Second Thoughts on Substantive versus Functional Definitions of Religion" Journal for the Scientific Study of Religion 13(2): 125-133. https://www.jstor.org/stable/1384374

Bornstein, E. 2003. The Spirit of Development: Protestant NGOs, Morality, and Economics in Zimbabwe. New York: Routledge.

Carbonnier, G. 2013 International Development Policy: Religion and Development. London: Palgrave Macmillan

Change Institute. 2009. "The Nigerian Muslim Community in England: Understanding Muslim Ethnic Communities" London: Communities and Local Government. http://thinkethnic.com/wp-content/uploads/2012/02/Nigerian\%20Muslims\%20in\%20UK.pdf

Chant, S. and C. Mcllwaine. 2009. Geographies of Development in the 21st Century An Introduction to the Global South. London: Edward Elgar Publishing

Clarke, G., and M. Jennings. 2008. Development, civil society and faith-based organizations: bridging the sacred and the secular. Basingstoke: Palgrave Macmillan. 
Clough, P., and K. Nutbrown. 2012. A Students Guide to Methodology. London: Sage Publications.

Davies, R. 2012. "African diasporas, development and the politics of context" Third World Quarterly 33(1): 91-108. doi:10.1080/01436597.2012.627237

De Castro, M.C., and A. Dawson. 2017. Religion, Migration, and Mobility: The Brazilian Experience. Abington: Routledge.

Deneulin, S., and M. Bano. 2009. Religion and Development: Rewriting the Secular Script. London: Zed Books.

Denscombe, M. 2010. The Good Research Guide for Small Scale Research Projects. Buckingham: Open University Press.

Garbin, D. 2017 "Sacred remittances: money, migration and the moral economy of development in a transnational African church" Journal of Ethnic and Migration Studies.

Gilbert, N. 2008. Researching Social Life. London: Sage Publications.

Goodhew, D. 2012. "Conclusion: The Death and Resurrection of Christianity in Contemporary Britain." in Church Growth in Britain: 1980 to the Present, edited by Goodhew. D., 253-257. Aldershot: Ashgate.

Imoagene, O. 2017. Beyond Expectations: Second-Generation Nigerians in the United States and Britain. California: University of California Press.

Jones, B., and M.J. Petersen. 2011. "Instrumental, Narrow, Normative? Reviewing recent work on religion and development" Third World Quarterly 32(7): 1291-1306. doi:10.1080/01436597.2011.596747.

Kenny, K. 2013. Diaspora: A very Short Introduction. New York: Oxford University Press.

Laakso, L., and P. Hautaniemi. 2014. Diaspora, development and peacemaking in the horn of Africa. London: Zed Books.

Maurice, N. 2014. Voices of the Diaspora: A New Vision. UK: BUILD.

Meynaud, J. 1969. Technocracy. California: Free Press.

Mostafanezhad, M. 2013. "Getting in Touch with Your Inner Angelina: Celebrity Humanitarianism and the Cultural Politics of Gendered Generosity in Volunteer Tourism." Third World Quarterly 34 (3): 485-499. doi:10.1080/ 01436597.2013.785343.

Office for National Statistics. 2011. "2011 Census: Ethnic group, local authorities in the United Kingdom" UK: Office for National Statistics. https://www.ons.gov.uk/peoplepopulationandcommunity/populationandmigration/population estimates/bulletins/keystatisticsandquickstatisticsforlocalauthoritiesintheunitedkingdom/2013 $-10-11$ 
Onwuegbuzie, A.J., N.L. Leech. 2007. "Sampling Designs in Qualitative Research: Making the Sampling Process More Public." The Qualitative Report, 12(2): 238-254.

Onwuegbuzie, A.J., N.L. Leech and K.M. Collins. 2010. "Innovative Data Collection Strategies in Qualitative Research.” The Qualitative Report, 15(3): 696-726.

Rakodi, C. 2007. Understanding the role of religions in development: The Approach of the RaD Programme, Working Paper 9. Birmingham: Religions and Development.

Rogers, A. 2013. Being Together: A Story of New Black Majority Churches in the London Borough of Southwark. https://www.roehampton.ac.uk/BeingBuiltTogether/Research/

Selinger, L. 2004. "The Forgotten Factor: The Uneasy Relationship between Religion and Development” Social Compass 51(4): 523-543. doi:10.1177/ 0037768604047872.

Smith, B.M., N. Laurie., P. Hopkins., and O. Elizabeth. 2013. "International volunteering, faith and subjectivity: Negotiating cosmopolitanism, citizenship and development" Geoforum 45: 126-135. https://doi.org/10.1016/j.geoforum.2012.10.010

Stevanovic-Feen, N. 2012. "Remittances and the Moral Economies of Bangladeshi New York Immigrants in Light of the Economic Crisis." PhD Diss., Columbia University.

The Independent. 2013. "Remittances could be as sustainable as international development finance." blogs.independent.co.uk/2013/06/15/remittancescould-be-as-sustainable-asinternational-developmentfinance

The Muslim Council of Britain. 2015. "British Muslims in Numbers" http://www.mcb.org.uk/wp-content/uploads/2015/02/MCBCensusReport_2015.pdf

Ver Beek, A.V. 2000. "Spirituality: a development taboo" Development in Practice, 10(1): 3143. doi:10.1080/09614520052484.

Walters, J. 2018. Religious Imaginations: How Narratives of Faith Are Shaping Today's World. London: Gingko Library.

Wilcock, C. 2017. "Mobilising towards and imagining homelands: diaspora formation among U.K. Sudanese" Journal of Ethnic and Migration Studies, 44: 363-381. doi:10.1080/1369183X.2017.1313104

World Bank. 2018. "Migration and Remittances: Recent Developments and Outlooks" The World Bank Group https://www.knomad.org/publication/migration-and-development-brief-29 